Fanum

Sociológico

\section{Forum Sociológico}

Série II

$18 \mid 2008$

Explorando os interstícios urbanos

\title{
Eyes Wide Shut: (Re)Situando a questão da Exclusão Social
}

Leonidas K. Cheliotis

\section{(2) OpenEdition \\ 1 Journals}

Edição electrónica

URL: https://journals.openedition.org/sociologico/304

DOI: 10.4000/sociologico.304

ISSN: 2182-7427

Editora

CICS.NOVA - Centro Interdisciplinar de Ciências Sociais da Universidade Nova de Lisboa

\section{Edição impressa}

Data de publição: 1 junho 2008

Paginação: 103-121

ISSN: 0872-8380

\section{Refêrencia eletrónica}

Leonidas K. Cheliotis, «Eyes Wide Shut: (Re)Situando a questão da Exclusão Social», Forum

Sociológico [Online], 18 | 2008, posto online no dia 03 dezembro 2012, consultado o 31 março 2022

URL: http://journals.openedition.org/sociologico/304 ; DOI: https://doi.org/10.4000/sociologico.304

Este documento foi criado de forma automática no dia 31 março 2022.

(c) CICS.NOVA 


\title{
Eyes Wide Shut: (Re)Situando a questão da Exclusão Social
}

\author{
Leonidas K. Cheliotis
}

Começo ${ }^{1}$ este artigo com a versão argentina de um mito urbano que se popularizou. Quando Juan e Evita Péron decidiram construir uma propriedade de luxo situada algures no exterior de Buenos Aires, longe das decadentes villas miserias onde habitam as pobres populações migrantes, um rígido sistema de vigilância foi montado para prevenir assaltos. Na dita propriedade, todos os dias por volta do meio-dia um trabalhador aparecia no portão de saída com um carrinho-de-mão carregado de palha. Os guardas, para evitar que algo de suspeito se passasse por debaixo das suas barbas, inspeccionavam sempre a palha com grande minúcia. Contudo, para sua desilusão, nunca descobriam nada de ilegal. Até que, um ano depois, um dos guardas mais desconfiados se decidiu a confrontar um dos trabalhadores cujo negócio, por estes dias, prosperava. "Afinal de contas", perguntava o guarda cedendo à sua própria curiosidade e revelando alguma inveja e admiração pelas bem-sucedidas explorações deste seu conhecido, "posso saber o que andas a roubar todos os dias da propriedade do senhor Péron?" Ao que o trabalhador, sussurrando ao ouvido do guarda, terá respondido: carrinhos-de-mão (Cerf, 1952: 64). Para o filósofo Slavoj Zizek, a lição a tirar deste episódio é curiosamente paradoxal: "Nunca nos podemos esquecer de incluir no conteúdo de um acto de comunicação o acto em si, uma vez que o significado de cada acto de comunicação reside também na asserção, que o próprio constitui, de que é um acto de comunicação" (Zizek, 2006: 21). Com efeito, é secundário que o desvio social possa tomar a forma de uma violação de regras sociais em termos que as próprias regras prevêem. Neste caso concreto, o que conta é que o trabalhador proferiu uma mentira estratégica para flanquear e se vingar do seu antigo opressor sem correr riscos de represália (isto é, sem violar, pelo menos explicitamente, as regras). Até a ocorrência do encontro entre os dois é, em último caso, irrelevante. o primeiro engano reside na nossa incapacidade em reconhecer que habitualmente as representações servem os interesses do "Senhor narrador" que "dilui narrativas potencialmente rivais numa plataforma comum, assim as preterindo para uma posição marginal" (Kearney, 1994: 493). Ou, como Zizek afirma, "o engano (reside) no nosso fracasso em incluir na lista de 
suspeitos a própria ideia de suspeita (generalizada). (...) Esta é a primeira coisa a reter sobre a forma como o inconsciente funciona: o inconsciente não está escondido no carrinho de mão, é o carrinho de mão" (Zizek, 2006: 21).

Parece haver um "efeito carrinho de mão" no modo como sociedades exclusivistas são produzidas e reproduzidas. Que o fenómeno nasça, perdure e até cresça à vista desarmada ocorre, simplesmente, porque a sua natureza e as suas causas fundamentais tendem a escapar à nossa compreensão. $\mathrm{O}$ presente artigo ilustra a necessidade $\mathrm{e}$ estabelece os fundamentos de uma exegese da exclusão, quer enquanto explanandum isto é, enquanto puzzle a ser resolvido - quer enquanto explanans - ou seja, como instrumento hermenêutico - assim anatomizando a sua mecânica socio-espacial por forma a deslindar as ligações éticas implícitas entre ambos. Com este fim em vista, optei pela adopção da abordagem platónico-idealista, através da qual múltiplos exemplos, desde o gueto americano à banlieue parisiense, passando pelas prisões de ambos os lados do Atlântico, pela exterminação dos judeus durante a Segunda Guerra Mundial e pela actual mortalidade infantil do nordeste brasileiro, "indicam a vitalidade transcendente da ideia que expressam, sendo que a ideia corresponde ao referencial fixo de exemplos mutáveis" (Zizek, 1992/2008: xi). Passo a passo, os espaços geográficos são substituídos por espaços sociais, a hermética separação comunicativa cede perante a perceptividade incorpórea e a hipertrofria moral toma o lugar da indiferença moral. Se, como sugiro, a relegação cognitiva dos excluídos para o estatuto moral de seres inferiores é o que desperta as emoções necessárias para a participação em comportamentos de exclusão física (i. e., segregação, violência), obstruindo ainda os potenciais de empatia inerentes ao inevitável contacto face a face com o excluído, a desumanização cognitiva em si mesma só é possível através de mediações simbólicas prévias. Mediações essas que transcendem as fronteiras do tempo e do espaço com o fim último de diluir as formas de ver, de compreender, de sentir, de avaliar o mundo exterior ao self e a ele reagir estrita, ainda que subtilmente, de acordo com os diferenciais de poder que ambos reflectem e ajudam a suster.

\section{O modelo da 'Visibilidade-Zero' da Exclusão Espacial e da sua Auto-reprodução}

"Procuramos criar um ser não-humano no qual o sofrimento moral, a bondade de coração, o afecto, o amor e todos aqueles venenos corrosivos de inexaurível energia vital, quais ímpares interruptores da potente electricidade corporal do homem, serão abolidos" (Marinetti, 1972: 91, citado por Shanken, 2000).

4 Em primeiro lugar, importa notar que com o termo exclusão se pretende designar os processos de marginalização colectiva forçada a operar em vários sistemas sociais, económicos, políticos e culturais, incluindo a consequente desfiliação dos mesmos. Operando conjuntamente, são estes processos que integram os seres humanos numa sociedade. Portanto, para além da pobreza ou desvantagem económica, a exclusão acarreta consigo a falta de acesso a diversas e interligadas áreas tais como a da habitação, a dos serviços de saúde, a de um salário, a da educação, e a da justiça (Young, 1999). De forma ainda mais acutilante, também envolve o que Robert Sack descreve como uma forma estratégica de territorialidade, nomeadamente, "a tentativa de um indivíduo ou grupo influenciar, afectar, ou controlar objectos, pessoas, relações, limitando a área geográfica e exercendo controle sobre ela" (Sack, 1983: 56). São disso 
exemplo a segregação espacial de grupos desfavorecidos em enclaves urbanos muito degradados - sob condições de "encarceramento virtual", de acordo com a definição de Wacquant $(1996,126)$ - ou, para recorrer a um exemplo ainda pior, em armazéns sobrepopulados que são hoje o "estado da arte" no que diz respeito a estabelecimentos prisionais (Wacquant, 2001).

Bauman cedo associa a gestão dos espaços com os domínios das emoções e da ética. $\mathrm{Na}$ minha leitura, Bauman assume de forma implícita que o exercício de um juízo moral pressupõe uma faculdade de percepção simultaneamente cognitiva e emocional. Desta forma, capacidades emocionais e cognitivas operam em sinergia, assistindo-se mutuamente num esforço de compreensão da situação na qual nos encontramos (Vetlesen, 1994: 175). A percepção, façamos notar, informa o nosso juízo de valor e por consequência é, à vinda, informada por ele; e todavia, tal movimento pendular revelase irrelevante para o caso. Pois o "juízo de valor (e a tomada de acção subsequente) não vem a ocorrer nos casos onde uma das faculdades é, por alguma razão, impedida de participar activamente no processo" (ibid.: 157). Banindo ou suspendendo a comunicação, as práticas de isolamento geográfico (ou de clausura exclusiva, na terminologia Weberiana) servem então para abafar as pré-condições cognitivas e emocionais de qualquer juízo de valor, desta forma cultivando a sua própria reprodução, de consequências catastróficas. Assim, como nos diz Bauman no quadro da sua abordagem geopolítica da instituição prisional:

“O processo de «estranhamento» ('estrangement') reduz, estreita e comprime a percepção do outro; as qualidades individuais e as circunstâncias que tendem a ser tão vivamente trazidas ao conhecimento pela experiência acumulada da socialização contínua e diária, raramente saltam à vista quando o contacto social é reduzido ou impedido: a tipificação social toma então o lugar de familiaridade pessoal, e as categorias legais transportam consigo a redução da variedade dando lugar à irrelevância do carácter único das pessoas e das circunstâncias. Quando, de forma forçada, se encontra numa condição de reduzida familiaridade, mantida e cultivada no interior das fronteiras de um espaço supervisionado de perto, mantido à distância e barrado do acesso comunicativo, seja ele regular ou esporádico, o Outro é alienado ficando permanentemente fechado e selado nessa condição, sendo portanto «apagado» - despido da sua genuinidade, a única característica que permitia contrariar a estereotipificação e ultrapassar ou mitigar o impacto redutor da lei - incluindo da lei penal" (Bauman, 2000: 27-8).

6 Contudo, este seria ainda assim um diagnóstico demasiado indulgente, para não dizer enganador, associando a prioridade temporal à genuinidade da pessoa humana enquanto objecto de "estranhamento". É todavia a qualidade humana da pessoa que, no caso, é desafiada logo a partida. Ainda que seja verdade que a negação da individualidade corresponde à negação de uma dimensão intrínseca à humanidade, a segregação espacial e a perca de visibilidade perseguem o "anterior" (porque "superior") fim, o de deserdar o invisível da pertença à humanidade, uma humanidade na qual a individualidade não é mais do que uma qualidade acessória. Este parece ser cada vez mais o caso nas prisões mais rudimentares do mundo anglo-americano (ver Sparks, 1996, 2007), ou, ainda mais, no campo de detenção "sem-lei" de Guantanamo em Cuba - o "equivalente legal da dimensão extra-espacial", como a ele se referiu um advogado da administração Bush (Sands, 2008). $O$ alienado de Bauman, deste ponto de vista, não é nada mais do que o homo sacer de Giorgio Agamben, o morto-vivo dos campos de concentração Nazi, "aquele que pode ser morto mas não sacrificado", o legado antropomórfico da "Lei Romana arcaica, na qual a vida humana é incluída na 
ordem jurídica (ordinamento) somente sob a forma de exclusão (ou seja, da sua capacidade para ser morto)" (Agamben, 1998: 8). Ou, para usar a linguagem aristotélica que o próprio Agamben repete, o alienado é aquele a quem é vedada não apenas a oportunidade de uma vida boa e qualificada, própria de indivíduos verdadeiramente distintos (eu zen) mas também o reconhecimento dos outros como pertencente à espécie humana, o acesso físico a lugares onde pode viver em comum com outros homens e por vezes até o direito à própria vida prática (zen).

7 Bauman parece tomar este aspecto em consideração nos seus estudos iniciais, quando discute as condições sociais que levaram ao Holocausto. $\mathrm{O}$ próprio refere a invisibilidade natural da própria humanidade das vítimas enquanto "comprimidos para dormir morais" necessários para transformar os indivíduos - que não são, em nenhum dos sentidos "normais" da palavra, "degenerados morais" - em assassinos ou colaboradores conscientes dos assassínios (Bauman, 1989: 26, 24). Em primeiro lugar, o distanciamento visual das vítimas e a sua consequente redução a entidades desalmadas anula qualquer possibilidade de identificação em simultâneo com a obsolescência de todas as inibições morais contra a dor aflitiva que sobre elas se abate. Não há nada que ameace o ânimo dos perpetradores, nem, consequentemente, nada de humanamente imoral em tratar não-humanos de forma desumana. Mas, como Bauman também aponta, de mão dada com a perda de visibilidade das vítimas e da sua humanidade está a perda de visibilidade do seu número. Por seu turno, esta situação expropria o ser humano da sua capacidade para a compaixão ou o que Hannah Arendt descreve como "a piedade animal que todos os seres humanos sentem quando confrontados com o sofrimento dos outros" (Arendt, 1964: 106, citada por Bauman, 1989). Toda a procura no sujeito de defeitos morais ou de qualquer tipo de causalidade interna donde pudesse resultar uma esperada auto-responsabilização se revela assim absolutamente insignificante, para não dizer masoquista. $O$ relato de Bauman merece ser citado em maior detalhe:

"Com a morte «à distância», a ligação entre carnificina e actos totalmente individuais - como o puxar de um gatilho, o ligar da corrente eléctrica, ou o pressionar de um botão - acaba por ser puramente teórica (tendência a que muito ajuda a mera discrepância entre o resultado e a sua causa imediata - uma incomensurabilidade que facilmente desafia a compreensão, baseada que esta está na experiência do senso comum). É portanto possível sermos um piloto que lança uma bomba sobre Hirochima ou Dresden, atingirmos níveis de excelência nos deveres que nos são consignados numa base de mísseis, construirmos ogivas nucleares cada vez mais devastadoras - e tudo isto sem recuarmos na nossa integridade moral ou sem nos aproximarmos do colapso moral. (...) (No mesmo sentido, as câmaras de gás) (...) reduziram o papel do assassino àquele de mero «inspector sanitário» a quem é solicitado que deposite uma quantidade determinada de «químicos desinfectantes» na brecha do telhado de um prédio, o interior do qual ele não terá sido incitado a visitar" (Bauman, 1989: 25-26).

Em última análise, se os juízos de valor são ou não baseados em emoções e na cognição humana, ou estes últimos nos primeiros, nenhum processo pode ser iniciado, e ainda menos conducente à mudança, na ausência de um sujeito reconhecido nesse direito. 


\section{Quão totais são as Instituições Totais? Algumas considerações preliminares sobre os limites funcionais da exclusão espacial}

Começámos por traçar o papel crucial que processos de mediação podem desempenhar na gestão de comportamentos morais, isto é, no exercício de um controle exógeno sobre as acções ou inacções de uma pessoa enquanto ser moral. Todavia, um passo atrás parece ser aqui imperativo. Pois não importa quão monolítica a segregação socioespacial possa parecer à primeira vista, não é necessariamente equivalente à separação comunicativa ou a uma total invisibilidade. Nem tão pouco preenche sempre as funções alienantes tão vividamente descritas por Bauman. Ao nível mais imediatamente tangível do que John Thompson (2005: 35) classifica de "visibilidade situada de copresença" esta dicotomia pode ser pensada por analogia com a comparação de Wacquant entre o hipergueto afro-americano de fim de século e a situação dos imigrantes nos bairros periféricos das metrópoles europeias (i. e., a banlieue parisiense), este último correspondendo a um universo racial e culturalmente mais homogéneo, caracterizado por uma baixa densidade organizacional e uma baixa penetração do estado, sendo o primeiro "tipicamente heterogéneo em termos etno-raciais e recrutamento de classe, como uma presença comparativamente mais forte de instituições públicas e uma profunda penetração estatal" (Wacquant, 1996: 122; Mooney e Danson, 1997). Ao contrário do caso homólogo americano, e tendo em conta as diferenças entre as respectivas heranças urbanas, lógicas exclusivistas e políticas governamentais próprias de cada lado do Atlântico, "as concentrações de imigrantes, tal qual existem (nas periferias metropolitanas do continente) não são o produto do fechamento do grupo dentro de fronteiras espaciais rígidas, como evidenciado pelas altas taxas de casamento interracial e difusão espacial quando a educação e a posição de classe melhoram" (Wacquant, 1998: 1645). Enfim, sem querer pintar um quadro cor-derosa, as condições traumáticas das zonas urbanas mais pobres que existem por essa Europa fora, não é por acaso que estratos diferentes podem partilhar o mesmo contexto espacio-temporal e assim entrarem em contacto físico directo uns com os outros.

Na sua crítica à tese da "cidade dual" proposta pelos teóricos da ecologia humana, e ecoada na descrição que Bauman faz de Washington, Jock Young vai ao ponto de duvidar que o típico gueto americano se possa classificar como uma zona urbana claramente demarcada do resto da cidade:

"Pois as fronteiras são regularmente cruzadas e a língua falada de cada lado é muito semelhante. $\mathrm{O}$ género parece ser aquele elemento ao qual o argumento não se aplica: empregadas, enfermeiras e freiras deslocam-se para o trabalho todos os dias atravessando essa «fronteira». As mulheres, como William Julius Wilson avança no livro When Work Disappears, são mais aceitáveis para quem esta de fora do gueto, do que pelos seus próprios parceiros. São os homens que ficam em casa - e dai a designação de «home boys». Taxistas, pequenos comerciantes, porteiros e pessoal da manutenção regularmente fazem o seu caminho através das fronteiras invisíveis de Washington. (...) Os trabalhadores pobres sustentam o estilo de vida dos trabalhadores ricos: de facto, só a disponibilidade de ajuda «fácil» é que viabiliza a sobrevivência de famílias de carreira dupla (Young, 1999: 471-2).

11 De forma ainda menos tolerante (na acepção qualificada de Derrida), qualquer tentativa localizada para reprimir hermeticamente as massas requer, ironicamente, que o espaço cívico urbano seja "primeiro" estruturado, ou reestruturado, em consonância com a 
inclusão, em vez de exclusão. Como Keyth Hayward explica, "para a vigilância gerir os seus sujeitos desviantes, moldando, dando forma, e assegurando em último lugar conformidade de conduta, aqueles sujeitos devem estar dentro do perímetro e não fora dele" (Hayward, 2004: 139). Em geral, e seja qual for a razão da interpenetração das barreiras físicas, "para que o processo de polarização social possa ser verificado, temos que analisar tal noção à luz de um escrutínio mais rigoroso da estrutura espacial em causa" (Van Kempen, 1994: 1001).

Neste momento imagino alguns dos leitores a obstarem ao uso da analogia sociotopográfica de isolamento involuntário no caso de periferias degradadas e da visibilidade situada do mundo prisional. De facto, hoje não são apenas o hipergueto e a prisão a caracterizar-se por uma "homologia estrutural", compreendendo e acomodando os mesmos tipos de relações sociais e padrões de autoridade (i.e., divisões raciais entre subordinados, a cultura supermasculinista da rua, a localização de uma população maioritariamente negra sob a supervisão de brancos). Também estes revelam uma "equivalência funcional", tendo como missão comum a de purgar os indesejáveis. O modelo prisional parece, a esta luz, ainda mais prometedor (Wacquant, 2001). Mas, por muito difícil que seja defender que os muros visíveis da prisão são tão porosos como as fronteiras invisíveis do gueto americano, ou mesmo da banlieue parisiense, não deixa de haver fortes razões para um certo cepticismo quanto ao grau de separação comunicacional entre prisioneiros, sugerida por Bauman e Wacquant. Basta dizer que apesar do actual boom da encarceração, práticas barbáricas de ostracismo e exílio como as da deportação de condenados para colónias penais distantes, ou a imposição sobre os mesmos de trabalho escravo, não pertencem a um passado distante. Abu Ghraib, na periferia de Bagdade no Iraque, Guantanamo, em Cuba, ou mesmo os vários campos e prisões secretas que existem pelo mundo inteiro, continuam a ser excepções perturbantes, até do ponto de vista do próprio excepcionalismo americano ${ }^{2}$. Na verdade, por razões pragmáticas como o transporte de prisioneiros, a procura de um staff adequado, a disponibilidade de vários tipos de bens especializados, materiais, e serviços, o potencial nefasto das prisões reavivarem economias rurais (i.e., em termos de taxas de empregabilidade, receitas financeiras, e comércio regional) leva a que sejam agora situadas na vizinhança das comunidades locais donde provêem os detidos, mais do que em áreas remotas e despovoadas (Farrington, 1992; Murray, 2007; Applegate \& Sitren, 2008).

Ora uma vizinhança deste tipo não torna eo ipso as fronteiras menos porosas. Num extremo do espectro, a mancha de marginalidade moral que associamos aos menos privilegiados vem a par com a estigmatização territorial e é por esta reproduzida. No caso da França, Les Minguettes e La Courneuve ou o complexo habitacional de Mirail em Toulouse são disso exemplo; nos Estados Unidos, Los Angeles centro-sul, o Bronx e o projecto de Cabrini Green em Chicago; no caso alemão, Duisberg-Marxloh e BerlinNeuköln; em Inglaterra, os casos de Toxteth em Liverpool, Saint Paul em Bristol ou a propriedade de Meadow Well em Newcastle em Inglaterra; e ainda, na Holanda, os casos de Biljmer e Westlijke Tuinsteden em Amesterdão. Não só estas zonas metropolitanas ficam reservadas aos párias do Primeiro Mundo, argumenta Wacquant, elas "são vistas e reconhecidas publicamente como buracos negros urbanos onde a violência, o vício e o abandono fazem parte do quotidiano" (Wacquant, 2008: 238; ver ainda Girling et al., 2000; Sparks et al., 2001). Passando do 'encarceramento virtual' para o seu protótipo, o simbolismo negativo dos muros prisionais de grande perímetro nas áreas residenciais, 
ou na sua proximidade, parece desencorajar o envolvimento das comunidades, mas também reforçar o que é hoje comum designar por "síndroma NIMBY" (not-in-mybackyard syndrome). Como o próprio termo sugere, e apesar do apoio público generalizado ao uso do encarceramento como uma estratégia de controle criminal, a presença de uma prisão numa dada comunidade tende a provocar grande consternação e traz consigo a hostilidade dos bairros mais próximos (quanto mais não seja pelo medo generalizado que a fuga potencial de detidos inspira) e, enquanto corolário potencial de tudo isto, de vitimização criminal futura (Martin e Myers, 2005) ${ }^{3}$. As construções prisionais, assim, desempenham a dupla função psíquica que a mitologia tradicionalmente reserva a monstros e outras figuras míticas e que esta de acordo com a etimologia binária do termo latino monstrare: eles mostram $e$ avisam, relembrandonos que o ego não é sempre inviolável.

Uma resposta espontânea seria, e em alguns casos foi, a de desenvolver e manter uma rede de prisões de segurança máxima em edifícios do tipo fortaleza que, apesar de situados no campo imediato de visão da comunidade livre, prometem isolar "totalmente" as populações de detidos dentro das suas paredes e mantê-los afastados dos bairros, casas e lojas locais. Os exemplos mais característicos destes fortes, situados na proximidade das comunidades por forma a "manter o inimigo cá dentro em vez de lá fora" (Gresham Sykes, 1958: 3), são o Maryland Correctional Adjustment Centre na baixa de Baltimore, o ADX Florence no Colorado, Attica no estado de Nova Iorque, Belmarsh em Londres, La Santé em Paris, San Vittore em Milão, e o complexo prisional de Korydallos em Atenas, para mencionar apenas alguns. Sem sombra de dúvida, os locais, bem como qualquer pessoa que esteja apenas de passagem, ter-se-iam maravilhado com Andrew Derbyshire (2003: 56) quando afirmou que "os arquitectos tentam cuidadosamente estabelecer um interface público atractivo, procurando, numa arquitectura urbana sensível, um equilíbrio entre a necessidade de o edifício parecer acessível e os necessários símbolos prisionais que inspiram orgulho cívico" (Será Derbyshire da opinião que o betão de tom laranja-rosa, como no trágicómico caso de San Vittore em Milão, possa alguma vez passar por maravilha da cenografia urbana? Não sabemos.) Mas temos, em vez disso, uma tentativa de inverter, de forma homeopática, o papel que a arquitectura desempenha na gestão das sensibilidades públicas: procura-se compensar a péssima experiência da proximidade geográfica de uma prisão com a presença de uma prisão austera e esta deslocação estética deve portanto inspirar um forte sentimento de segurança. Uma mitigação sublime, mesmo que parcial e temporária, dos medos que os edifícios prisionais servem e animam. Ibi sunt dracones, ("ali vivem dragões") para parafrasear o famoso aviso de Lenox Globe, e ali devem permanecer. $\mathrm{O}$ cidadão normal pode agora dormir em paz pois o Estado está a fazer alguma coisa para combater o crime e as inseguranças ontológicas que o crime gera (a acrescentar àquelas que inconscientemente remove $)^{4}$.

Seja como for, Keith Farrington relembra que nem todos os sistemas correctivos podem custear a construção de verdadeiras "instituições totais", nomeadamente, instituições onde "um grande número de indivíduos, postos à parte da sociedade por um período considerável de tempo, levam uma vida formalmente administrada e fechada" (Goffman, 1961: xiii):

"É um facto bem conhecido que é mais caro construir e manter aquele tipo de infraestruturas "megaprisionais" de segurança máxima que, no mínimo, tendem para um modelo de instituição total, do que construir e administrar instituições menos seguras, ou alternativas verdadeiramente não-institucionais de encarceramento. 
Assim, apesar de ambos cidadãos e oficiais de governo serem favoráveis ao encarceramento de alta segurança num contexto institucional total enquanto pedra angular da sua luta contra o crime, esta alternativa pode simplesmente ser uma impossibilidade económica nalguns casos. (...) O encarceramento em massa é um grande negócio, e, eventualmente, há muito dinheiro em jogo. E, quanto mais totais são as instituições em questão, mais dinheiro estará envolvido" (Farrington, 1992: 11).

Esta é a principal razão pela qual, ao tempo deste artigo, o número de estabelecimentos de segurança máxima em Inglaterra e no País de Gales remontava a 8 prisões - uns meros 6 pontos percentuais num total de 139 estabelecimentos. Que os estabelecimentos locais tenham sido historicamente o maior sector do sistema prisional inglês não constitui qualquer surpresa. Como Sparks expressou tão vividamente, "a prisão local geral" (ou então, a "brecha local" "local nick") é o sistema prisional inglês (Sparks, 1971: 90)5. A isto podemos acrescentar a expansão recente da reintegração na comunidade e outros programas semelhantes que, apesar de aludirem com frequência a preocupações financeiras e de sobrelotação, ainda assim encurtaram, de alguma forma, a distância entre a prisão e o mundo exterior, ou proporcionando aos prisioneiros a oportunidade de circular mais ou menos livremente entre nós (Cheliotis, 2006) ${ }^{6} \mathrm{ou}$ exigindo a entrada de falanges de psicólogos, assistentes sociais, pedagogos, voluntários, organizações não-governamentais, advogados, assessores jurídicos, doutores, psiquiatras e criminólogos nas prisões para oferecerem os seus serviços especializados, quaisquer que sejam as suas implicações.

Neste sentido, o meu argumento é o de que a invisibilidade física do microcosmo prisional é menos total e hipostasiada do que o sugerido por Bauman e Wacquant. Mas isso não é tudo.

\section{E viveram felizes para sempre: Faces carentes, 'Histórias tristes' e o despertar da empatia}

“Incapaz de escapar a si próprio: eis o Eu” (Levinas, 1961: 245).

Até aqui, a análise deixa uma margem significativa para optimismo. Podemos supor, como a exclusão espacial pertence a um Zeitgeist do passado, que o que surge acessibilidade territorial e uma crescente reciprocidade visual - devia normalmente funcionar como um ponto de amparo para a identificação, compaixão e, se necessário, uma intervenção moral mais adequada. Até podemos ir ao extremo de reformular a hipótese ex positivo. Isto é, a proximidade física e a visibilidade têm de facto o potencial intrínseco de inspirar mais do que a simples unidade e compaixão, e até mais do que amor. Podem igualmente induzir empatia, ou, posto de outra forma, criar "capacidade de ser afectado pela afectividade do outro" (Vetlesen, 2005: 11) assim ajudando a construir, em terra firme, a ponte entre abismos estereotípicos e a inclusão socioespacial.

Como oposta à identificação interpessoal, a empatia consiste no "reconhecimento da alteridade de duas pessoas, da sua diferença e carácter distinto enquanto algo que deve ser mantido e não anulado" (Vetlesen, 1994: 204). E, portanto, a empatia está "na retenção, e não no abandono, da posição e identidade do sujeito no seu esforço de reconhecimento do outro enquanto outro" (idem). Da mesma forma, a empatia difere da compaixão (em particular, da ideia de compaixão presente em Schopenhauer): a 
empatia "ocorre porque a tua dor é tua e não minha, porque nós somos seres humanos individuais e separados; o chamamento pode ser correspondido porque somos todos seres humanos, partilhando, através das nossas faculdades emocionais, da mesma experiência de dor" (ibid.: 207). Para circunscrever todos estes contrastes, a empatia, ao contrário do amor, "pode ser direccionada para pessoas que não nos são especiais e que não amamos. (...) A pessoa com quem crio empatia é olhada como diferente, mas não como única, pelo menos não no sentido mais forte de ser, para mim, insubstituível e impagável" (ibid.: 204)7.

Como seria expectável, a função e natureza dual da empatia - orientada para o outro assim como para o próprio reconhecendo e sustendo a alteridade - impõe à performance moral critérios de avaliação mais elevados. Pois o objecto de avaliação moral não é mais aquele que produz uma reacção emocional e cognitiva no sujeito, mas é sim o próprio sujeito. "As minhas atitudes para com os outros reflectem-se nas minhas atitudes para comigo mesmo; para ser capaz de me olhar no espelho como uma pessoa digna, tenho que alcançar um determinado nível nos meus sentimentos, pensamentos e atitudes perante os outros" (ibid.: 160-161). Se, então, e concordando com Vetlesen, a empatia traz consigo um peso moral inter e intra-pessoal maior do que a dos seus parentes mais intangíveis e passageiros (identificação, compaixão, amor), a pergunta que urge fazer é a seguinte: qual é o grau (e quais as condições) de proximidade física e de visibilidade que pode facilitar a sequência em questão?

É pouco provável que atitudes classificatórias e redutoras sejam adoptadas previamente como é pouco provável que sejam abandonadas assim que as pessoas chegam a acordo. É-nos dito frequentemente, por exemplo, que quanto maior o grau de intimidade física e social entre uma pessoa e o detido, menor a probabilidade de o último vir a ser fundamentalmente estigmatizado pelo primeiro (Rubingon \& Weinberg, 1973; Rock, 1973). Como escreve Richard Ericson, a propósito das múltiplas formas pelas quais os ex-detidos são tratados após a libertação, "pessoas próximas têm mais informação social ao seu dispor sobre o sujeito do que a maioria pessoas mais distantes, informação essa que permite abordar o sujeito tendo em conta vários aspectos da sua identidade social, envolvendo vários papéis sociais" (Ericson, 1977: 17). Não surpreende portanto que "em vez de evitar ser "contaminado" dissociando-se do seu filho (anteriormente detido), é provável que os pais unam esforços com o sujeito estigmatizado, num esforço colectivo de demanda de uma identidade convencional. (...) Entre aqueles que apenas «têm conhecimento do», em vez de "conhecerem o» sujeito (...) há uma diferença abismal de reacção" (ibid.: 22, 23). Apesar da observação de Ericson dizer somente respeito à componente do juízo de valor, não é difícil ver como a intimidade física e social pode potenciar o contacto também por via das emoções. $O$ amor dos pais desempenha um papel tão importante quanto a sua cognição no reconhecer do outro enquanto ser humano, e ainda assim não necessariamente enquanto sujeito totalmente distinto. Para Ericson, o que está em jogo, apesar de tudo, não é a "alteridade" do outro enquanto merecedora do reconhecimento assumido e de direito próprio, mas a apresentação de uma qualquer imagem convencional passível de ser recebida favoravelmente por aqueles que estão do lado de fora. A transição inversa, do "O" maiúsculo do "Outro" para o "o" minúsculo do "outro" constitui pois um longo caminho a percorrer.

É no mesmo terreno analítico que Shadd Maruna e Thomas LeBel admitem a plausibilidade de um modelo de re-entrada baseado na auto-estima (strengths-based re- 
entry model), que vá para além da procura de um remédio para as necessidades dos infractores, e que os encoraje "a fazer remendos, a demonstrar o seu valor e potencial e a experienciar o sucesso em papéis de suporte e liderança" (Maruna e LeBel, 2002: 168). Esta abordagem, sugerem Maruna e LeBel, promove algum grau de "reintegração relacional" com efeitos a longo prazo, pois atribui aos detidos uma tarefa visível e com significado na comunidade (por exemplo, responsabilidade parental activa ou o trabalhos de conservação), resgatando o sujeito da estigmatização aos olhos da sociedade em geral e não apenas aos olhos daqueles que lhes são próximos. Como o significado corrente do termo sugere, contudo, a reintegração relacional pressupõe que os detidos foram uma vez parte incluída da sociedade em geral, senão no sentido aristotélico de um eu zen, pelo menos no sentido mais limitado de lhes ser permitida a partilha do mesmo espaço vivencial com qualquer outro cidadão. Mesmo que aceitemos este apriorismo tácito como verdadeiro (muitos diriam o devaneio), a reintegração moral poderia dificilmente ser completada na prática, isto é, ir para além da mera antropomorfização.

Maruna e LeBel não vão ao extremo de afirmarem que a reintegração relacional por si só serviria para equipar os infractores de oportunidades para uma distinção pessoal, indiferentes face às concepções pré-estabelecidas de bem na sociedade. Pelo contrário, o alerta que pretendo lançar é este: na sua forma actual, e no que respeita à sociedade em geral, o esquema conceptual da reintegração social privilegia a cognição em detrimento das emoções, dá azo a histórias paternalistas de "redenção merecida" em detrimento de "histórias tristes" e desafiantes e prefere um perdão e uma identificação racionalmente calculados à empatia espontânea. A reintegração social, tal como praticada hoje em dia, pode conduzir ao embargo das estruturas sociais de inclusão espacial que reflictam e facilitem uma noção de moralidade mais forte do que aquela que a realidade do dia-a-dia demonstra. A conjugação não-hierárquica e de efeitos normativos entre preocupação (enquanto cortesia do emocional) e respeito (enquanto cortesia do cognitivo-racional) que Vetlesen propõe, é iluminadora a este respeito:

“A preocupação que uma pessoa tem por outra é uma preocupação com o outro, uma preocupação na qual o estatuto de Outro, enquanto ser autónomo, é interpelado. Como tal, a preocupação pela outra pessoa, que devemos designar como uma preocupação moral ipso facto, contém o respeito pela integridade dessa pessoa, pelo direito inviolável dessa pessoa em decidir por ele ou por ela o que melhor serve os seus objectivos e interesses. Se este preceito não for observado, arriscamo-nos a confundir preocupação com paternalismo" (Vetlesen, 1994: 2).

A que devemos acrescentar que:

"Por difícil que seja conceber preocupação sem respeito, parece igualmente difícil conceber respeito sem preocupação. Acharíamos credíveis aquelas propostas que nos asseguram respeito pelos outros, «respeito» no sentido moral, tendo os mesmos faltado à demonstração de preocupação pela sorte e azar dos outros? Dificilmente. Neste caso, como no primeiro, quando um dos princípios exclui o outro princípio a sua pretensão de importância moral perde todo o sentido" (Vetlesen, 1994: 2).

No seu livro Making Good, Maruna parece aproximar-se de Vetlesen quando escreve que, "no Ocidente, de certa forma, nós exigimos uma "história triste" sobre os desviantes para os tornar perdoáveis" (Maruna, 2000: 145). Mas de novo, as "histórias tristes" que testam a nossa moralidade não são do tipo odeia o pecado, ama o pecador, onde outros oferecem neutralizações pelos seus actos e demonstram o seu potencial ético. Nem tão pouco são estas histórias que inspiram as nossas tentativas sobranceiras "de encontrar qualquer valor redentor no indivíduo" (ibid.: 142). A preocupação $e$ o respeito vêm ao 
de cima quando "histórias tristes" sobre os outros fazem tremer a moralidade das nossas próprias biografias até às suas raízes, quando nos confrontam com os nossos próprios pecados, quando, despertando a nossa empatia, a nossa culpa e a nossa vergonha encontram finalmente o seu caminho, em direcção às almas dos verdadeiros pecadores. Ou, como Maruna ele próprio prefere afirmar, quando deixa de ser fácil "desapropriármo-nos das nossas próprias sombras" (Maruna et al., 2004).

A intimidade física e social pode criar uma empatia espontânea e lançar uma luz significativa sobre as condições particularmente difíceis nas quais indivíduos ou grupos tendem a ser mais violentos que outros. 0 fracasso do outro em levar uma vida de acordo com os princípios do eu zen pode ser atribuído ao dado prévio de um zen precário, ou então, à redução do outro à "mera existência" (la nuda vita do homo sacer de Agamben). Como Levinas (1961) arguiu, o poder da face do Outro reside, paradoxalmente, na sua inconfundível expressão de pobreza e destituição. Ser confrontado com esta face não reforça apenas a interdição "Tu não deves matar"; "O Outro envergonha-me na minha liberdade arbitrária, que é sempre justificada porque apela ao ajuizar do Outro. (...) O juízo dá portanto origem à responsabilidade infinita da Vontade, mesmo que seja a Vontade de seres irredutivelmente distintos" (Alvares, 2006: 273).

A proximidade e a visibilidade promovem a empatia e previnem comportamentos violentos quando potenciam o apercebimento por parte do sujeito do envolvimento, passivo ou activo, involuntário ou deliberado, no sofrimento de outro ser humano. Tal ficou claro, por exemplo, na experiência de Stanley Milgram sobre a obediência e legitimação à autoridade, um exemplo celebrizado pelo contributo que deu para compreendermos melhor o Holocausto. Nesta experiência em que se procura averiguar a forma como a inflição do castigo pode afectar a aprendizagem e a memória, voluntários que desconheciam o facto de participarem numa experiência, foram convidados a entrar num laboratório na Universidade de Yale. Em seguida, foram instruídos por um alegado psicólogo (o "experimentador") para administrarem, em ritmo crescente, choques eléctricos a estudantes (na realidade, actores) que estavam numa sala ao lado, fora da vista, quando estes cometiam "erros" ao tentarem memorizar sequências de palavras. A verdadeira pergunta de investigação era "até que ponto pode o participante obedecer às instruções do experimentador sem lhes resistir" (Milgram, 1974/2004: 4-5). Em particular, o que nos interessa neste exemplo é um conjunto de três variáveis na experiência inicial, onde as "vítimas" e o seu sofrimento eram dadas a conhecer ao sujeito de forma cada vez mais imediata. Na condição dita de "feedback de voz", os protestos e as queixas das vítimas eram claramente audíveis através das paredes do laboratório; na condição dita de "proximidade", o sofrimento da vítima ficava situado no mesmo quarto onde permanecia o sujeito, a uma distância audível e visível; e, na condição de "contacto físico", a aplicação do castigo requeria contacto físico entre os dois lados, com os voluntários a terem eles próprios que pressionar a mão da vítima contra a máquina que emitia choques. Não surpreende que Milgram tenha concluído que "à medida que a vítima se aproximava do voluntário a quem tinha sido ordenado aplicar os choques, um número crescente decidia-se a cortar com a experiência, recusando obedecer. A presença concreta, visível e próxima da vítima actuou no sentido de contrariar o poder do experimentador e de gerar desobediência" (ibid.: 41). De acordo com Milgram, a proximidade física com o sofrimento da vítima não contribui apenas para produzir vantagens cognitivas tais 
sobre a humanidade das vítimas, ou para compreender a conexão entre as acções ou inacções e os seus efeitos prejudiciais nos outros. "É possível, explica Milgram, que os estímulos visuais que o sofrimento da vítima provoca despertem no voluntário respostas empáticas e lhe transmitam uma imagem mais cabal da experiência da vítima" (1974: 39). E, em virtude da então evocada faculdade de empatia, pode até darse o caso em que o sujeito sente que "ele próprio se expôs no campo perceptivo da vítima, consequentemente mais auto-consciente, envergonhado, e inibindo-o de punir a vítima" (ibid.: 40).

Seja qual for o ponto de vista, Zizek sugere que olhemos a face do Outro através de uma lente radicalmente contrária àquela que nos oferece Levinas. O verdadeiro passo ético" escreve Zizek, "é aquele que está para além da face do outro, é aquele que nos permite suspender o erguer da face, escolher contra a face, em favor do terceiro" (Zizek, 2006: 183). Ao invés de demonstrar meramente respeito pela face presente do outro, nós devíamos "abstrairmo-nos dela e concentrarmo-nos nos terceiros sem-face que estão por detrás. Só esta mudança de foco para o terceiro pode efectivamente extirpar a justiça, libertando-a do cordão umbilical contingente que a torna imbuída de particularismos" (ibid.: 183-41; ênfase original). A académica Lynne Henderson, especializada em Direito, parece concordar com Zizek quando defende que "a linguagem da emoção e da experiência", as narrativas pessoais que permitem apreciar os contextos sociais trágicos da conduta quotidiana e criar empatia com o sofrimento de outros companheiros, deveria ser o suplemento à "visão empobrecida da razão e do entendimento que caracteriza os discursos tradicionais de actos legais" (Henderson, 1987: 1575). A empatia é, para esta autora, "uma forma de conhecimento que explode com o conhecimento recebido de estruturas e terminologias legais, que revela problemas morais previamente sublimados através de pretensões racionais e redutoras, e que providencia uma ponte para resultados legais de melhor qualidade normativa" (ibid.: 1577). Em suma, Henderson "recorda a nossa humanidade comum e responsabilidade para com os outros" (ibid.: 1653).

Em suma, o reconhecimento da humanidade do outro pode salvar vidas. Mas viver uma vida assim está dependente de uma forma qualificada de visibilidade, que permita o acesso às emoções e assim o acesso ao mundo do ético. Pode ser que esse acesso só seja possível nos mundos ideais dos laboratórios e dos livros; mas admiti-lo seria contar mais uma triste história.

\section{Uma Realidade estilhaçada: 0 teorema de Merton}

31 Alguma forma de separação total entre o self e o outro, ou aquilo a que a antropóloga americana Nancy Scheper-Hughes (1992: 410), seguindo as pisadas de Maria Piers (1978), se referiu como o estado psicológico de "estranhamento fundamental", pareceme ser uma pré-condição necessária para praticar actos de exclusão física contra outras classes ou seres, como para os considerar naturais e inevitáveis. Mas o contrário revelase mais improvável: apesar das aparências a marginalização e a separação comunicativa não são necessariamente pré-condições de estranhamento. Assim como o continuum que vai da proximidade espacial à visibilidade física, ao contacto face a face e à familiaridade pode prevenir (à la Bauman) "o impacto redutor da lei", os mesmos podem igualmente dar origem a práticas de exclusão. Ou, nas palavras de Erving Goffman, "não é um adquirido que a familiaridade minimize o desprezo. É frequente 
acontecer que aqueles que vivem num espaço adjacente às «tribos de estigmatizados» mantenham vivo o preconceito" (Goffman, 1963/1990: 70). E não surpreende que, como a própria origem etimológica do termo preconceito sugere (em inglês, "prejudice": prae, pré (antes) + judicium, juízo), as raízes da exclusão residam nos juízos decorrentes dos "factos" crus da experiência directa.

No seguimento da apreciação das biografias daqueles que foram responsáveis por resgatar judeus durante a ocupação Nazi da Europa (e também daqueles que optaram por não o fazer), Federico Varese e Meir Yaish (2000) revelam que um pedido directo de ajuda aumentaria substancialmente a probabilidade de vir a ser resgatado, sobretudo se esse pedido fosse solicitado a uma pessoa próxima (por exemplo, amigos ou familiares). Contudo, Varese e Yaish estavam relutantes em fazer pedidos de ajuda directos dado o risco de os próprios despoletarem a empatia necessária para induzir qualquer observador a agir moralmente (ibid.: 328). Neste sentido, optavam por privilegiar os benefícios cognitivos que tais solicitações pudessem suscitar, dando lugar, no longo prazo, a juízos e acções morais. A importância de ser interpelado, concluíam eles, reside no seu potencial prático de fazer corresponder disposições empáticas a casos concretos de pessoas em dificuldades, permitindo ao mesmo tempo avaliar os riscos pessoais e particulares que acções altruístas acarretavam. Daí que a vergonha decorrente da decisão consciente de não agir não devesse ser

"exagerada por uma racionalização ex post, baseado na visão, comum no pós-guerra, que ajudar judeus em dificuldade constituía uma acção legítima. Para além disso, mesmo aqueles que não apoiaram as políticas Nazis no que ao genocídio diz respeito, podiam ser compelidos pelo dever de proteger as suas próprias famílias. Nestas circunstâncias, as pessoas podem não ter sentido vergonha em dizer «não» a um pedido de ajuda que, a ser correspondido, poria em perigo iminente a sua família. Apenas aqueles que sentiam o dever de ajudar - sem que na verdade o quisessem fazer - se sentiriam culpados" (ibid.: 322).

Pondo de parte a contabilização dos custos, parece justo afirmar que as conclusões de Milgram relativamente às relações espaciais e o seu pesado efeito sobre os processos psicológicos que medeiam o nosso comportamento perante os outros, seriam fundamentalmente diferentes tivesse Milgram aplicado a variável de desumanização de Abert Bandura (1975) às condições ditas de "proximidade" e de "contacto físico" na sua própria experiência. Trata-se de um pergunta retórica, mas quantos participantes teriam desobedecido à ordem de punir se tivessem tido conhecimento de que as vítimas eram um "bando de animais inúteis"? Ou ainda, quantos se teriam abstido de um comportamento violento se as vítimas tivessem sido previamente rotuladas de exNazis?

Esta é, de resto, o resultado da prioridade que é dada aos alegados traços desviantes sobre todas os outros processos de identificação - o que Howard Becker, no seguimento de Everett Hughes, designou como master status (1963: 33). Eles "atenuam a nossa ânsia em obter (mais) conhecimento (do indivíduo ou do grupo em questão)" (Schur, 1971: 30, citado por Ericson, 1977). Não surpreende portanto que muitos empregadores nos Estados Unidos pré-seleccionem, de entre os demais candidatos, aqueles que habitam em guetos (Wacquant, 2008). Ou que detidos libertados temporariamente suscitem nos civis atenção e hostilidade, mesmo que comportamentos problemáticos ou recaídas se verifiquem apenas numa pequena percentagem de casos. Ou que detidos em licença de trabalho tendam a sofrer de exploração alheia e reduções salariais desproporcionadas às condições de habitação e alimentação providenciada por essa licença ${ }^{8}$. Ou, que civis 
iraquianos detidos sejam atormentados, humilhados e torturados por soldados americanos em Abu Ghraib. Chocante, sim. Surpreendente, não.

Nem os laços de parentesco, bem como a intimidade física e social que lhes é inerente, podem ser tomados à partida como salvaguardas suficientes contra o desenvolvimento do "master status" e as respectivas consequências atrozes. Em contraste radical com o cenário cor-de-rosa pintado por Ericson, existem sinais abundantes a sugerirem que o estigma do encarceramento desestabiliza as relações matrimoniais e familiares na maioria dos detidos, muitas vezes de forma irremediável (Uggen et al., 2005: 221-227). Podemos até apontar inúmeras histórias de abuso de mulheres que terão pretensamente sido co-responsáveis na sua própria vitimização, ou mencionar os inúmeros casos de pessoas condenadas a uma morte física e social indigna em lares e instituições de acolhimento empobrecidos dos Estados Unidos, vítimas não apenas do cinismo institucional e da indiferença profissional, mas também da "passividade letal" dos seus próprios descendentes (Scheper-Hughes, 2002: 40-4). O antropólogo Anton Blok vai ao ponto de inverter o argumento, sugerindo que a proximidade geográfica é um forte percursor do master status na base de comportamentos exclusivistas. Na sua recensão de trabalhos etnográficos sobre as formas de guerra intertribais, que vão desde guerras civis na ex-Jugoslávia e Ruanda à perseguição dos Burakumin no Japão e aos linchamentos que se seguiram à abolição da escravatura na América do Sul, Blok mostra como, inter alia, os confrontos ocorrem frequentemente entre bairros vizinhos como resultado da estigmatização. "Como os Mae Enga nas terras altas da Papua Ocidental costumam dizer: Nós casamo-nos com aqueles contra quem lutamos." (Blok, 2001: 119)

36 Sem dúvida que W. I. Thomas estava certo ao fazer notar que "se os homens conceberem as situações como reais, elas tornam-se reais nas suas consequências" (Thomas, 1928: 572). Mas, como Robert Merton contrapõe, o "subjectivismo total" ou a perspectiva segundo a qual a realidade social consiste apenas em definições, percepções, rótulos, crenças, assunções e desejos "acaba por transformar o Teorema de Thomas numa falácia: se os homens não definirem as situações enquanto reais, elas não são reais nas suas consequências" (Merton, 1976: 175, ênfase original). O conselho de Merton é pois o de nunca perder de vista as forças objectivas (demográficas, económicas, ecológicas e outras) que influenciam a acção humana e as suas múltiplas consequências. Na frase do sociólogo Arthur Stinchcombe, que tempera o ênfase subjectivo de W. I. Thomas com o ênfase objectivo de Karl Marx, "se as pessoas definem situações, não as definem como querem?" (ibid.; Stinchcombe, 1975: 15-16). Que situações socialmente induzidas possam ainda regozijar o Self actuante não deve ser factor de desnorte; a experiência do prazer individual, que frequentemente implica sofrimento para os outros, não é sempre real na sua definição. "Precisamos então necessariamente deste contrapeso ao Teorema de Thomas: se os homens não definirem situações reais como reais, elas terão ainda assim consequências reais. (...) Em sociedade, como noutros domínios, o que tu não sabes (ou não notas) pode magoar-te" (Merton, 1976: 177). Dito ao contrário: se distorcido, o que tu sabes ou notas pode magoar-te. Como a muitos outros.

37 A necessidade deste salto conceptual é corroborada pelo facto destes conhecimentos classificatórios e definições socialmente estandardizadas existirem e persistirem, não apenas contra a visibilidade do estigma em causa, mas também independentemente desta. Como é que é possível, por exemplo, que ex-detidos assumam um estatuto quase 
arquetípico de desprezados da comunidade quando tendem, na sua maioria, a esconder de seus conhecidos ou até das pessoas que lhes são mais próximas, esse lado negro da sua identidade pessoal (Murray, 2007)? Em última análise, o que está em causa não pode ser apenas o adágio de que quanto mais virmos uma pessoa, melhor a conheceremos; em causa está, em vez disso, o carácter pluriforme da visibilidade, das suas raízes, ritos, lugares, sujeitos e efeitos. As experiências subjectivas de contacto pessoal e até de familiaridade decorrentes da transgressão das fronteiras espaciais não podem simplesmente ser atribuídas às flutuações históricas e sociais ou às contingências políticas e individuais. Nem tão pouco se manifestam de forma visível e directa nos fluxos humanos que entram e saem de localidades entrincheiradas. De facto o que se revela paradoxal é que enquanto restringirmos a nossa concepção de contiguidade social a uma "visibilidade situada de co-presença" fortuita, casual e fugidia então seremos levados a exagerar a difusão, a impermeabilidade e a longevidade da separação comunicativa, não conseguindo isolar a causa mais directa da exclusão: a penetração no substrato de estereótipos e simbologias que medeiam e modelam as maneiras de ver, compreender, sentir, julgar e reagir ao mundo exterior.

\section{O Poder do Conhecimento e o Conhecimento do Poder: Para além do Panóptico}

"O trabalho das emoções, para emprestar uma expressão feliz de Arlie Hochshild (1979), põe o corpo autoconsciente ao serviço do corpo político" (Scheper-Hughes, 1992: 412)."A conduta", insiste Vetlesen, "depende da percepção; depende de quem a (outra) pessoa 'é' para nós. Na percepção, a variável espacial é ultrapassada por variáveis sociais como a familiaridade e por variáveis extra-individuais tais como estereótipos ideológicos, a burocracia ou a tecnologia" (Vetlesen, 1994: 275). Por outro lado, e é aqui que paradoxalmente Vetlesen parece hesitar, a primazia atribuída à familiaridade é lida como uma premissa inerente ao contacto face-a-face, com efeito, contacto esse que não pode senão mobilizar desempenhos sociais geradores de empatia com o outro conhecido.

\footnotetext{
"Teria feito alguma diferença do ponto de vista do comportamento do sujeito se lhe tivesse sido dito que a vítima (...) era, de facto, alguém conhecido? o peso emocional que esta variável transporta em si - o conhecimento do outro ausente - teria atenuado a força que emana da variável espacial e inspirado uma crescente relutância no sujeito para continuar a provocar sofrimento" (ibid.: 274; ênfase original).
}

Por seu lado, "as variáveis extra-individuais como os estereótipos ideológicos, a burocracia e a tecnologia" são encontradas no campo oposto, comprometendo o potencial cognitivo, emocional e moral da noção metafórica de proximidade. Assim, "uma atrocidade de magnitude equivalente à da destruição dos Judeus exigiu, para que fosse concluída, não a mobilização do ódio mas a neutralização de qualquer sentimento" (ibid.: 273). Pois, mesmo que incapaz de distorcer a percepção, negando ao outro a pertença à humanidade, o ódio só

\footnotetext{
"constitui uma condição suficiente de imoralidade quando exercido à escala menor, num espaço onde a interacção é guiada por encontros face a face e de proximidade. $\mathrm{O}$ ódio, como qualquer outro móbil pessoal ou emocional, tende a tornar-se cada vez

mais supérfluo, e cada vez menos letal, quando condições de imoralidade são
} 
criadas num contexto de larga escala onde a interacção é despersonalizada, as tarefas são rotinizadas e as atitudes profissionalizadas" (ibid.: 275). ainda a possibilidade do contacto com o outro através da suspensão da nossa própria imoralidade. Donde resulta não apenas o ódio mas um qualquer móbil emocional que se pode tornar fatal quando emana de um grau suficiente de "desumanização" dos outros, alicerçado que está na exclusão cognitiva da ordem moral de pertença à espécie humana ${ }^{9}$. O que está em causa então não é a exclusão espacial, mas sim o processo, sempre por concretizar, de inclusão na categoria de pessoa humana - o que Durkheim já antecipava com o conceito de sacralização da pessoa (Joas; 2008). De facto, esta sequência de desumanização, emoções cruas, e destruição invertem o rácio social e espacial do lugar físico; quanto maior o lugar físico da exclusão e quanto mais despersonalizada a interacção que nele se dá, maior a "relutância" cognitiva, emocional e moral do sujeito para provocar sofrimento. A nossa concepção da gestão do espaço deve portanto ser repensada pois não há nada que ameace o entusiasmo daqueles que cometem as atrocidades, nem, consequentemente, nada de humanamente imoral em tratar sub-humanos de forma desumana. Como Fromm afirma,

“assim como precisamos de armas para travar uma guerra, precisamos dos sentimentos de ódio, indignação, destruição e medo que mobilizem milhões de pessoas para se tornarem assassinos, arriscando as suas vidas. Estes sentimentos são condições necessárias para a condução de uma guerra; não são menos a sua causa do que as armas e as bombas. Muitos observadores comentaram que a guerra nuclear difere a este respeito da guerra tradicional. o homem que carrega no botão lançando mísseis nucleares, um dos quais poderá matar centenas de milhares de pessoas, dificilmente terá tido a experiência de matar alguém tal como um soldado a viveu quando usou da sua baioneta ou metralhadora. Porém, ainda que o lançamento de uma bomba nuclear seja, em consciência, nada mais do que a obediência convicta a uma ordem, permanece a questão se em estratos mais profundos da personalidade existe, senão um impulso destrutivo, pelo menos uma enorme indiferença perante a vida, para que tais actos sejam possíveis" (Fromm, 1964: 22-23).

Como o próprio Vetlesen vem a admitir no seu mais recente trabalho:

"o contexto no qual o mal levado a cabo pelos Nazis é irredutivelmente triádico, onde a vítima não é perdida de vista, mas ao invés permanece um foco - um foco cujo significado não é nada mais do que o de deixar o mal à sua auto-legitimação enquanto algo que tem inevitavelmente que ser feito" (Vetlesen, 2005: 27).

O objectivo do meu trabalho é portanto o de redimensionar o papel das três variáveis extra-individuais - estereótipos, burocracia $e$ tecnologia - que produzem as percepções que temos dos outros e assim legitimam a prática colectiva do mal contra eles ${ }^{10}$. Contudo, no que resta do presente artigo, irei concentrar-me quase exclusivamente na produção colectiva de estereótipos.

Um ponto de partida útil é o trabalho de Michel Foucault sobre os conceitos de "poder", "conhecimento" e "racionalidade", enquanto relacionados com a forma, a cultura, e as práticas do castigo e do controle social modernos e pós-modernos. No seu influente "Vigiar e Punir", Foucault (1979) empresta de Bentham o ideal setecentista do Panóptico prisional, com o seu inspector omnisciente e todo-observador bem escondido na torre central e as suas células expostas a radiarem para todo o perímetro, para descrever o que ele concebe como uma mudança qualitativa fundamental na "microfísica do poder". Esta mudança consiste na passagem de um sistema arcaico de 
dominação e controle sociais e penais, pressupostos e reforçados pelo espectáculo de subjugação aberta e violenta do corpo na sua forma corpórea, para um aparato não menos tirânico, ainda que certamente mais subtil, tendo em vista o disciplinar do espírito por meio de regras institucionais minuciosamente prescritas, acopladas a uma vigilância constante (ou, pelo menos, à ilusão de uma vigilância constante). Este sistema tem portanto como objectivo a criação de um corpo "auto-controlado" sem que para tal seja preciso recorrer à força física. Os rituais de pompa magna de tortura em público, característicos do ancien régime, deram lugar, segundo Foucault, ao encarceramento panóptico, uma forma mais discreta de castigo onde o detido, consciente do todopoderoso olhar das hierarquias superiores, "assume a responsabilidade pelos freios do poder; fá-los operar espontaneamente sobre si mesmo; inscreve em si próprio a relação de poder na qual desempenha dois papéis ao mesmo tempo; transforma-se assim no princípio da sua própria sujeição" (ibid.: 202-3). Na medida em que tornar os corpos dóceis e desta forma manipuláveis nunca deixou de ser o objectivo último das instituições penais (e de todas as outras instituições estatais como escolas, hospitais, e, a esse propósito, o exército), então a vigilância total e o conhecimento atento dos "alvos" em causa evoluíram no sentido de se tornarem, eles próprios, os meios mais eficientes da sua realização.

A visibilidade é portanto uma metáfora do conhecimento, e, como tal, relaciona-se inextricavelmente com o exercício de poder. Posto de outra forma, as assimetrias na visibilidade servem incessantemente para reproduzir as assimetrias de poder/

/conhecimento das quais são elas próprias um produto. Paradoxalmente, se as assimetrias funcionais de visibilidade forem mantidas, então as assimetrias poder/ conhecimento devem permanecer obscuras. Daí que Andrea Brighenti nos fale da necessidade de entender o poder panóptico não apenas em termos de uma assimetria de visibilidade de primeira ordem entre observadores e observados num dado espaço físico onde as assimetrias são necessariamente visíveis, mas em termos de um diagrama lógico alargado, consistindo numa "assimetria de visibilidade de segunda ordem, entre aqueles que estão cientes da existência do diagrama e aqueles que não sabem da sua existência" (Brighenti, 2007: 336, ênfase original). Ecoando Gilles Deleuze, a observação de Brighenti permite libertar, por assim dizer, a dialéctica entre o guarda prisional e o detido dos estritos limites da prisão, recolocando-a ao invés no centro de um modelo analítico geral onde o poder e o conhecimento que o invisível sustém acaba sendo directa e subtilmente extrapolado pelo visível, representado ora pelo detido ora pelo guarda, submetidos que estes estão também a alguma forma de vigilância. (Newburn e Hayman, 2002)

Dentro de instantes voltarei às formas específicas pelas quais as assimetrias de visibilidade de segunda ordem podem ser reproduzidas a diferentes níveis sociais. Como preliminar geral para tais considerações, contudo, podemos pôr em questão o argumento de Foucault sobre o papel crucial de formações discursivas estratégicas na relativização da verdade cosmológica e na reprodução de poder. Na Arqueologia do Saber, Foucault (1972) distingue entre o "visível" e o "articulável", sendo o primeiro o estético visível e o último o semiótico que dá ao estético a sua forma e conteúdo. Foucault associa, em grande parte, o articulável com o discursivo, ou por outra, com um conjunto particular de afirmações já disponíveis para fazer sentido do mundo exterior num dado momento histórico. Na medida em que as "coisas" adquirem significado no contexto de um discurso - e Foucault, na sua fase inicial, como é sabido, vai ao ponto de sugerir que nada tem significado fora do discurso -, não é por acaso que o poder 
procure regular, antes de mais, as informações discursivas através das quais nós interpretamos seja o que nos for permitido ou proibido observar. Que o poder também tente estabelecer os limites do visível (quem vê o quê e em que termos) só justifica o primado do articulável, pois o objectivo latente aqui não é outro que não o de fazer com que o primeiro se integre no último e o reforce ${ }^{11}$ (Hallsworth e Young, 2008). Em último lugar, como o próprio Foucault reconhecerá mais tarde na sua fase pós-epistemológica, a tarefa do genealogista é a de desvendar as linhas de continuidade entre significados idênticos e díspares, não como relações logocêntricas de significado, mas como relações de poder significativas. $O$ que autoriza o genealogista a traçar a história das relações humanas não é a sua relação ao nível da linguística, mas "a inteligibilidade de lutas, estratégias e tácticas" (Foucault, 1980: 114). Ou, para emprestar os termos de Wacquant, o que precisamos é de dissecar visões e divisões, os imbricados mecanismos simbólicos e materiais que inscrevem "fronteiras na objectividade do espaço social e na subjectividade do espaço mental" (Wacquant, 1997: 225).

Na medida que a luta pelo poder é simbólica na sua base, o discurso é ao mesmo tempo um campo de batalha e uma arma. Uma estrutura "estruturante" e "estruturada" que providencia os meios para entender o mundo assim como constitui o medium através do qual mundividências são comunicadas e difundidas (Bourdieu, 1991: 164-166). Daí que o processo da produção, reprodução e apropriação de certas visões do mundo social permitam às pessoas não apenas a representação mas a sua própria constituição como grupos distintamente identificáveis face a outros. $\mathrm{O}$ que conta como distintivo das classes até então formadas não é a posse ou a privação dos meios de produção, nem mesmo alguma forma de consciência colectiva, pelo menos não no sentido marxista tradicional. As classes, como sustenta Bourdieu, são conjuntos de agentes que partilham um sentido de pertença inconsciente, isto é, disposições perceptivas similares resultantes da sua posição no espaço social, precisamente porque ocupam nele posições semelhantes ou vizinhas (ibid.: 235). Acresce ainda o facto das disposições consolidarem as posições que expressam ficando assim completo o círculo de violência simbólica.

"Se o mundo social tende a ser olhado como evidente e "a ser captado", para usar os termos de Husserl (1913/1983), "numa modalidade dóxica", isso acontece porque as disposições dos agentes, o seu habitus, isto é, as suas estruturas mentais através das quais eles apreendem o mundo social, são essencialmente o produto da internalização de estruturas próprias desse mundo. À medida que as disposições perceptivas tendem a ajustar-se à posição, os agentes, mesmo os mais desprivilegiados, tendem a olhar o mundo como natural e a aceitá-lo muito mais facilmente do que se possa pensar - especialmente quando olhamos para a situação do dominado pelos olhos sociais do dominador" (Bourdieu, 1989: 18).

Mas ainda assim:

"As diferenças socialmente conhecidas e reconhecidas existem apenas para um sujeito capaz não apenas de reparar nas diferenças, mas sobretudo de as reconhecer como significativas e interessantes, isto é, existem apenas para um sujeito dotado da aptidão e da inclinação para estabelecer as diferenças que são consideradas significativas no mundo social em apreço" (Bourdieu, 1991: 237).

Na medida em que "a autoridade é trazida para a linguagem a partir de fora, como Benveniste (1969: 30-37) nos recorda na sua análise do skeptron entregue, de acordo com Homero, ao orador que se prepara para iniciar um discurso" (Bourdieu e Wacquant, 1992: 147), não é de admirar que o poder para inculcar e difundir uma visão das divisões sociais seja directamente análogo ao capital simbólico. Isto é, "o poder que 
é assegurado àqueles que obtiveram reconhecimento suficiente para estar numa posição a partir da qual podem impor o reconhecimento alheio" (ibid.: 23). Ainda para mais em situações de crise, quando o significado do mundo deixou de ser claro, como nos tradicionais Kabylia, onde o trabalho da produção simbólica conferiu aos poetas funções políticas mais elevadas como as de senhor de guerra ou embaixador (Bourdieu, 1991). Enfim, a tarefa do genealogista é a de desvendar os processos através dos quais a propriedade dos meios de produção cultural ganha efeito, a eterna "luta simbólica pela produção de senso comum e, mais precisamente, pelo monopólio do nomeação legítima como imposição oficial - isto é, explícita e pública - da visão legítima do mundo social" (ibid.: 239, ênfase original). E, "para dar conta desta acção à distância, esta transformação real efectuada sem contacto físico, nós devemos, como por magia (Marcel Maus (1902-3/1950)), reconstruir a totalidade do espaço social no qual são engendradas as disposições e crenças que tornam a eficácia da magia da linguagem possível" (Bourdieu e Wacquant, 1992: 148).

Ao sublinhar o papel regenerativo do discurso e a corpos formalizados de conhecimento, assim vindicando uma verdade absoluta, Bourdieu, ao contrário de Foucault, não irá porém tão longe ao ponto de apontar categorias subalternas tais como a do criminoso e do doente mental, limitando-se a casos gerais como o aparelho de estado, as suas agências, funcionários e acções (Wacquant, 2005). Nem, em qualquer circunstância, presta Bourdieu atenção suficiente a instâncias de violência física directa, preferindo tratar tais instâncias como modos de dominação anti-económicos, desnecessários, menos eficientes, e certamente menos legitimáveis, desta feita juntamente com Foucault. Com base na noção iluminadora de Franco Basaglia de 'crimes de paz' (crimini di pace), o antropólogo Nancy Scheper-Hughes descreve, ao invés, "um tipo de continuum genocidário, composto de uma multitude de "pequenas guerras e genocídios invisíveis" conduzidos, e legalmente previstos, em espaços sociais normais: escolas públicas, clínicas, salas de emergência, casas de repouso, sanatórios, instituições penais, prisões e morgues públicas" (Scheper-Hughes, 2002: 32). A tentativa desta antropóloga revela-se ambiciosa na medida em que procura expandir a observação feita com extremo cuidado por teóricos do estado para quem a violência não é reconhecida por causa da sua própria familiaridade, assim descurando formas explícitas de poder nu e violento. Com esse fito, Scheper-Hughes associa a naturalização da violência genocida a processos discursivos prévios de desumanização das vítimas e a várias pré condições emocionais e morais do mal deste modo formados, desde a mera indiferença do efeito observador ao ódio ardente, assim justificado. "As pequenas guerras e os genocídios invisíveis (...) são invisíveis não porque sejam mantidos em segredo ou escondidos do olhar público, mas pelas razões contrárias. Como observou Wittgenstein, as coisas mais difíceis de compreender são aquelas que estão diante dos nossos olhos, e são, como tal, tomadas como certas" (ibid.: 37).

Se, como Marx defendia, "a crítica da religião é o pré-requisito de toda a crítica" (Marx, 1844), parece adequado ao propósito deste artigo tomar o exemplo de Deus como um produto do estruturalismo linguístico. "Deuses" escreve Kearney, "são os nomes dados pela maior parte das mitologias e religiões àqueles seres cujo poder espiritual e misteriosidade extravasam a nossa compreensão e nos convidam a ajoelhar e a venerar. Às vezes são benignos, outras vezes cruéis e caprichosos. Por vezes, prossegue Kearney, confusos, apressamo-nos a fazer do outro um monstro e um Deus (...) As mutações de Zeus, desde o touro rapace ao cisne voraz epitomizam este paradoxo" (Kearney, 2003: 
4-5). No impressionante estudo etnográfico sobre (m)othering que Scheper-Hughes desenvolveu no Nordeste Brasileiro, somos confrontados com a realidade de crianças tremendamente doentes e famintas que são deixadas morrer prematuramente "por negligência" (à míngua) pelas suas mães desesperadas. De acordo com as próprias mães, apesar de "enviadas por Deus", as crianças "tinham de ser", e de facto "desejavam ser", devolvidas ao céu e santificadas, para nessa condição contribuírem para o bem-estar do seu lar. Tal era a imagem consciente ou inconscientemente construída e difundida de uma vontade divina supramundana donde resultava o papel ambivalente das crianças, ora "condenadas", ora "anjinhos". Uma destas mulheres afirmava que,

"Deus leva-as (as crianças) para nos salvar do sofrimento... Deus conhece o futuro melhor do que eu ou do que tu. Se o neném continuasse vivo iria provocar muito sofrimento à mãe. Podia tornar-se um ladrão, um assassino, um cabo safado, um Zéninguém. E é por isso que eles morrem ainda nenéns, para nos poupar de toda a dor e sofrimento, não para nos fazer sofrer" (Scheper-Hughes, 1992: 394).

51 O eco do discurso hegemónico empregue pela própria Igreja Católica Romana e aqui bem audível, seja na forma antiga e convencional de apologia da "paciência e resignação face à morte de crianças e a outras tragédias domésticas, ditas reveladoras dos trabalhos imponderáveis da vontade de Deus", ou, sob a nova máscara da teologia da libertação, mantendo-se mudo face à sua própria contribuição histórica para a morte dos infantes, "qual culatra ensanguentada em ruptura flagrante com os ensinamentos pró-vida e pró-natalistas da hierarquia" (ibid.: 419). A triste ironia não consiste tanto no papel proteico atribuído a Deus enquanto criador benevolente e cínico reivindicador de vidas, nem tão pouco no sacrifício que representa abandonar crianças "à sua sorte" (ou melhor, morte) ao abrigo de uma teodiceia muito oportuna na qual o nascimento das crianças é lido como um sinal da graça divina, mas cuja pavorosa sobrevivência pode até contradizer a Sua grandiosa Vontade. Antes, dando valor moral ao estoicismo aparente das mulheres, ela está na conjugação do sagrado com o profano que ajuda a reproduzir "a indiferença social e política face à sobrevivência e bem-estar de mães e crianças das favelas brasileiras" (ibid.: 412), ficando essa indiferença por desafiar.

Não que os pobres e doentes de Palo Alto sejam invariavelmente levados por valores religiosos que justifiquem a subordinação e a miséria - uma situação que James Scott (1990: 72) designaria como uma "forma espessa" de falsa consciência. Em última análise, contudo, "permanecem cépticos face a propostas radicais e revolucionárias, e dão o seu melhor para sobreviver em face das dificuldades da vida quotidiana e aproveitando ao máximo as oportunidades que lhes sobram (...) sob a sombra de uma impotência consciente" (Scheper-Hughes; 1992: 508). Contudo, desde que o seu objectivo seja apenas a existência, e não a resistência, as pessoas do Alto são ditas sofrerem de uma forma "estreita" de consciência falsa (também), onde "a ideologia dominante cultiva a aquiescência dos grupos subordinados, persuadindo-os de que a ordem social na qual vivem é natural e inevitável" (Scott, 1990: 72). E, se John Gaventa estiver correcto, a instilação prévia de consenso e de fatalismo nas massas "pode permitir (às elites) maior poder para investir no desenvolvimento de imagens dominantes, de legitimações, ou de crenças acerca do (seu) poder pelo controle, por exemplo, dos media ou de outras instituições de socialização" (Gaventa, 1980: 22). "Talvez seja esta a razão pela qual práticas maternais de uma estóica 'negligência mortal' tais como as do racionamento da comida das crianças enfermas e 'condenadas' com o objectivo de fazer acelerar a sua morte não exclui uma boa dose de contacto 
físico com as pequenas e pobres 'criaturas' ou a expressão de piedade pelas mesmas" (Scheper-Hughes, 1992: 410).

53 A confortável conjugação do sagrado com as mundanidades brutais do dia-a-dia podem igualmente manifesta-se a um nível mais acessível para o estudioso (ainda que permanecendo igualmente no inconsciente das massas), lá onde um conjunto de emoções agressivas que parecem justas se combina para assim legitimar atrocidades ainda maiores. Para tomar o exemplo mais conhecido de todos, tão cedo nos deixamos impregnar da retórica política que rodeia a corrente "guerra contra o terrorismo", que logo somos confrontados com complicações de ordem cósmica ou metafísica ou com o perigo iminente dos dogmas religiosos do Islão (o mesmo, claro está, pode ser dito da Jihad da Al Qaeda contra o Ocidente). O mesmo se passa com a religião ateísta pós-cristã do humanismo (Coker, 2001: 148). Como Mitchell Dean escreve, na sua crítica à tese de Agamben de que o excepcionalismo sem normas tende crescentemente a surgir como o paradigma dominante da política de guerra ocidental, "a guerra contra o terrorismo (...) não conhece limites legais por causa da sua vilificação do inimigo em inimigo absoluto", isto é, "um novo e pérfido inimigo não-estatal que pelas suas acções tem vindo a conduzir uma guerra não-declarada, uma guerra agressiva, contra a humanidade civilizada" (Dean, 2007: 171). Relembremos a este propósito a observação de Jean Baudrillard que cada poder necessita de um poder rival para que alcance um "equilíbrio de terror" sob a forma de uma "oposição regulada" (Kearney, 2003). Não é que, numa guerra apresentada como justa, estejamos perante o "vale-tudo", mas aos olhos do Ocidente "pode ser necessário suspender os valores liberais para assim os defender" (Dean, 2007: 172; Schmitt, 1950/2003). Donde a referência de Edward Said a um mundo caricatural onde Popeye e Bluto se golpeiam mutua e impiedosamente e onde o pugilista mais virtuoso acaba sempre por dominar o adversário (Said, 2001; citado por Kearney, 2003).

Mas voltemos de novo ao paradoxo: para manter as aparências da moralidade, a mediação triunfa sobre a aniquilação enquanto experiência social. "À medida que se torna mais tecnológica", diz-nos Christopher Coker, "a guerra distancia a opinião pública das acções do soldado, e estes das consequências daquela. Assim conduz inevitavelmente àquilo a que os psicólogos dão o nome de dissociação, cessando portanto de ser uma experiência intersubjectiva (e como tal ética)" (Coker, 2001: 149). Enquanto Coker, como Bauman e Vetlesen, traça inicialmente uma mudança de paradigma desde o (i)moral ao amoral, o seu instanciar da distância na guerra do Golfo revela o contrário. Que as câmaras instaladas nas bombas raramente captem o momento do impacte e os seus efeitos atrozes opera no sentido da representação (ou da semi-representação) da experiência imoral como experiência moral, transformando uma guerra desumana numa guerra aparentemente humana. Assim como, de facto, o uso conhecido das chamadas "smart-bombs", isto é, de bombas inteligentes com o fim suposto de minimizar "danos colaterais". "Pois uma Guerra é humana não só quando aparece nas televisões, mas quando suscita o interesse da sociedade de um modo humano". A distância de segurança assegura portanto o distanciamento moral não pelo adormecer das emoções e das questões sobre o que está certo ou errado, mas porque faz das emoções e dos males morais meros pormenores discursivos, limitando o campo de alternativas possíveis. Assim, é fácil "dar-mos connosco a fazer um uso impune da violência, sem capacidade para um juízo crítico. Deixaremos então de prestar atenção 
aos detalhes das questões éticas que todas as guerras (mesmo as mais justas) levantam" (Coker, 2001: 149-50).

Kearney pergunta-se (e responde) se ainda assim "não estaremos nós de tal forma presos a sistemas binários de pensamento que se torna inconcebível sair deste matrix labiríntico? Se tal for o caso, não há resposta para a questão sobre o que é que deve ser feito? E isso é inaceitável" (Kearney, 2003: 128). De facto, a teologia deve abrir avenidas discursivas à resistência contra a opressão. Kearney, por exemplo, sugere que, enquanto a instrumentalização da religião é o que está na base da "guerra contra o terrorismo", uma reavivar da visão da não-violência em diversas "tradições de sabedoria religiosa podem ser um antídoto" (Kearney, 2005). De forma não muito diferente, John O'Neil fala da necessidade de ler o imperativo categórico (no sentido kantiano de obrigação moral última guiando a acção humana) em termos da teologia política bíblica que subscreve a resistência ao self como fonte de reificação do outro ("a firmeza do sentir/do olhar/do ouvir" O'Neil, 2009). Mas voltemo-nos agora para as conclusões metodológicas que podemos tirar com vista ao exercício genealógico sobre fenómenos menos pacíficos e mais concretos.

\section{O Outro e a universalidade do Particular}

Em tempos tão essencialistas como os que vivemos, onde a exclusão socio-espacial da Alteridade conhece uma expansão ilimitada em inúmeros âmbitos, não é uma surpresa que até os especialistas (com ou sem aspas) ignorem a diversidade de mecanismos simbólicos e materiais pelos quais diferentes aspectos das divisões sociais são forjadas, reforçadas e desafiadas ao longo de horizontes temporais e geográficos variáveis. Sem dúvida que Bourdieu e Wacquant nos convidariam a inverter esta consideração, considerando tal desleixo académico ou semi-académico, não como fruto do acaso, mas precisamente como mais um exemplo de um poderoso mecanismo simbólico tão convenientemente esquecido. O mesmo é dizer que, ora empurrado por intenções nobres destituídas de reflexividade, ora levado pela vaidade do intelectualismo académico, ou ainda pela mera subserviência a diktats políticos e económicos, muitos autores se auto-situam na "lógica mono-dimensional do tribunal científico da prova", transformando conceitos analíticos próprios desta ou daquela sociedade, instituição ou grupo em instrumentos de uma condenação moralista indiscriminada. Para tomar o exemplo do "racismo",

"a maioria da investigação mais recente sobre desigualdade etno-racial no Brasil insiste em provar que, contrariamente à imagem que os brasileiros têm da sua própria pátria, o país das "três tristes raças" (povos indígenas, negros descendentes de escravos e brancos que ficaram da colonização e das ondas de emigração europeia) não é menos "racista" que os outros, e que os "brancos" brasileiros não têm que sentir ciúme dos seus primos norte americanos a esse respeito. Pior ainda, o racismo mascarado brasileiro devia por definição ser olhado como algo de mais perverso precisamente por ser dissimulado e renunciado" (Bourdieu e Wacquant, 1999: 44).

“A investigação histórica é desta forma aproveitada para a empresa colectiva de expiação intelectual onde a mancha da sujeição racial é simbolicamente lavada do corpo académico. O problema é que tal expiação contribui pouco, antes pelo contrário, para nos aproximarmos do fenómeno em causa e penetrarmos na sua composição" (Wacquant, 1997: 225). 

utilidade de cada uma das estruturas analíticas "universais", ou pelo menos não na medida em que os seguintes critérios epistemológicos forem rigorosamente observados: 1. delimitação das dimensões cognitivas, emocionais e morais e das modalidades do ser humano, sem nunca perder de vista as suas interligações maleáveis e funcionais; 2. separação entre "lugares-comuns" e noções analíticas, problematizando sempre os primeiros à luz das segundas; 3. distinção entre questões de motivo, de causa e de efeito; 4. diferenciação entre níveis de exegese dentro, e através, das várias constelações sociais de poder próprias de cada sociedade; 5. escrutínio das origens estruturais dos fenómenos bem como da responsabilidade dos seus agentes ${ }^{12}$.

Em jeito de conclusão, se pretendermos descrever de forma completa e também ajudar a entravar fenómenos de exclusão, então precisamos de dar um passo atrás e trazer para debaixo da nossa lupa os processos sociais levados a cabo pela mão humana e através dos quais as percepções das massas, as suas emoções e juízos morais são formados, substanciados e orientados em sentidos reaccionários. Para muitos, esta nota deve ser óbvia. Mas elaborar uma teoria que seja adequada às complexidades do fenómeno da exclusão social constitui um desafio que tem que ser confrontado de uma vez por todas.

\section{BIBLIOGRAFIA}

AGAMBEN, G. (1998), Homo Sacer: Sovereign Power and Bare Life, Stanford, Stanford University Press.

ALVARES, C. (2006), Humanism after Colonialism, Oxford, Peter Lang.

ARENDT, H. (1964), Eichmann in Jerusalem, New York, Viking Press.

BANDURA, A., B. Underwood e M. E. Fromson (1975), “Disinhibition of Aggression through Diffusion of Responsibility and Dehumanisation of Victims", Journal of Research in Personality, 9 (4), pp. 253-269.

BAUMAN, Z. (2000), “Social Uses of Law and Order”, in D. Garland e R. Sparks (eds.), Criminology and Social Theory, Oxford, Oxford University Press, pp. 23-45.

BAUMAN, Z. (1998), Globalization, Cambridge, Polity Press.

BAUMAN, Z. (1989), Modernity and the Holocaust, Cambridge, Polity Press.

BECKER, H. (1963), Outsiders: Studies in the Sociology of Deviance, Glencoe, Free Press.

BLOK, A. (2001), Honour and Violence, Cambridge, Polity Press.

BOURDIEU, P. e L. Wacquant (1999), “On the Cunning of Imperialist Reason”", Theory, Culture \& Society, 16 (1), pp. 41-58.

BOURDIEU, P. e L. Wacquant (1992), An Invitation to Reflexive Sociology, Cambridge, Polity Press.

BOURDIEU, P. (1991), Language \& Symbolic Power, Cambridge, Polity Press.

BOURDIEU, P. (1989), “Social Space and Symbolic Power”, Sociological Theory 7 (1), pp. 18-26. 
CERF, B. (1952), Good for a Laugh, New York, Hanover House.

CHELIOTIS, L. K. (2006), “Demystifying Risk Management: A Process Evaluation of the Prisoners' Home Leave Scheme in Greece", Criminology \& Criminal Justice: An International Journal, 6 (2), pp. 163-195.

COKER, C. (2001), Humane Warfare, London, Routledge.

DERBYSHIRE, A. (2003). “Architects and the Prison”, in L. Fairweather e S. McConville (eds.), Prison Architecture: Policy, Design and Experience, Oxford, Architectural Press, pp. 55-60.

ERICSON, R. (1977), “Social Distance and Reaction to Criminality”, British Journal of Criminology, 17 (1), pp. 16-29.

FARRINGTON, K. (1992), “The Modern Prison as Total Institution? Public Perception Versus Objective Reality", Crime \& Delinquency, 38 (1), pp.6-26.

FOUCAULT, M. (1980), Power/Knowledge, New York, Pantheon.

FOUCAUlT, M. (1979), Discipline and Punish: The Birth of the Prison, London, Allen Lane.

FOUCAULT, M. (1972), The Archaeology of Knowledge, London, Routledge.

FROMM, E. (1964), The Heart of Man: Its Genius for Good and Evil, New York, Harper \& Row.

GAVENTA, J. (1980), Power and Powerlessness: Quiescence and Rebellion in an Appalachian Valley, Urbana, University of Illinois Press.

GIRLING, E., I. Loader e R. Sparks (2000), Crime, Law, and Social Change in Middle England: Questions of Order in an English Town, London, Routledge.

GOFFMAN, E. (1963/1990), Stigma: Notes on the Management of Spoiled Identity, London, Penguin Books.

GOFFMAN, E. (1961), Asylums: Essays on the Social Situation of Mental Patients and Other Inmates, Garden City, NY, Anchor Books.

HAYWARD, K. (2004), City Limits: Crime, Consumer Culture and the Urban Experience, London, Glasshouse Press.

HENDERSON, L. N. (1987), “Legality and Empathy”, Michigan Law Review, 85, pp. 1574-1653.

HERZFELD, M. (2004), The Body Impolitic: Artisans and Artifice in the Global Hierarchy of Value, Chicago and London, The University of Chicago Press.

HUSSERL, E. (1913/1983), Ideas Pertaining to a Pure Phenomenology and to a Phenomenological Philosophy, First Book; General Introduction to a Pure Phenomenology, The Hague, Martinus Nijhoff.

KEARNEY, R. (2005), “Thinking After Terror: An Interreligious Challenge”, Journal of the Interdisciplinary Crossroads, 2 (1), pp. 1-24.

KEARNEY, R. (2003), Strangers, Gods and Monsters: Interpreting Otherness, London, Routledge.

KING, R. S., M. Mauer e T. Huling (2003), Big Prisons, Small Towns: Prison Economics in Rural America. Washington DC, The Sentencing Project.

KRAUSE, J. D. (1992), "The Effects of Prison Siting Practices on Community Status Arrangements: A Framework Applied to the Siting of California State Prisons", Crime and Delinquency, 38 (1), pp. 27-55.

LEVINAS, E. (1961), Totality and Infinity: An Essay on Exteriority, Pittsburgh, Duquesne University Press. 
MARTIN, R. e D. L. Myers (1992), “Public Response to Prison Siting: Perceptions of Impact on Crime and Safety", Criminal Justice and Behavior, 33 (2), pp. 143-171.

MARUNA, S., A. Matravers e A. King (2004), “Disowning our Shadow: A Psychoanalytic Approach to Understanding Punitive Public Attitudes", Deviant Behavior, 25 (3), pp. 277-299.

MARUNA, S. e T. LeBel (2002), "Revisiting Ex-prisoner Re-entry: A buzzword in Search of a Narrative", in S. Rex e M. Tonry (eds.), Reform and Punishment: The Future of Sentencing, Devon, Willan, pp. 158-180.

MARUNA, S. (2001), Making Good: How Ex-Convicts Reform and Rebuild their Lives, Washington DC, American Psychological Association.

MAUSS, M. (1902-3/1950), “Esquisse d'une théorie générale de la magie”, in Sociologie et Anthropologie, Paris, Presses Universitaires de France, pp. 1-141.

MERTON, R. K. (1976), Sociological Ambivalence and Other Essays, New York, The Free Press. MILGRAM, S. (1974/2004), Obedience to Authority: An Experimental View, New York, Harper and Row. MOONEY, G. e M. Danson (1997), "Beyond «Culture City»: Glasgow as a «Dual City»”, in N. Jewson e S. MacGregor (eds.), Transforming Cities, London, Routledge, pp. 73-87.

MURRAY, J. (2007), "The Cycle of Punishment: Social Exclusion of Parents and their Children", Criminology \& Criminal Justice, 7 (1), pp. 55-81.

NEWBURN, T. e S. Hayman (2002), Policing, Surveillance and Social Control, Devon, Willan.

O’NEILL, J. (2009), “Ecce Homo: On the Political Theology of Good and Evil”, in L. K. Cheliotis (ed.), Roots, Rites and Sites of Resistance: The Banality of Good, Basingstoke, Palgrave Macmillan.

PIERS, M. W. (1978), Infanticide, New York, W. W. Norton.

ROCK, P. (1973), Deviant Behaviour, London, Hutchinson.

RUBINGTON, E. e M. Weinberg (1973), Deviance: The Interactionist Perspective, New York, MacMillan.

SACK, R. D. (1983), "Human Territoriality: A Theory", Annals of the Association of American Geographers, 73 (1), pp. 55-74.

SCHEPER-HUGHES, N. (1992), Death without Weeping: the Violence of Everyday Life in Brazil, Berkeley, University of California Press.

SCHUR, E. (1971), Labeling Deviant Behaviour: Its Sociological Implications, New York, Harper and Row.

SCOTT, J.C. (1990), Domination and the Arts of Resistance: Hidden Transcripts, New Haven, Yale University Press.

SHICHOR, D. (1992), “Myths and Realities in Prison Siting”, Crime and Delinquency, 38 (1), pp. 70-87. SPARKS, R., E. Girling e I. Loader (2001), “Fear and Everyday Lives”, Urban Studies, 38 (5-6), pp. 885-898.

SPARKS, R. (1996), “Penal Austerity: The Doctrine of Less Eligibility Reborn?”, in R. Matthews e P. Francis (eds.), Prisons 2000, London, Macmillan.

SPARKS, R. (1971), Local Prisons: The Crisis in the English Penal System, London, Heinemann.

STINCHCOMBE, A. L. (1975), "Merton's Theory of Social Structure”, in L. A. Coser (ed.), The Idea of Social Structure, New York, Harcourt Brace Jovanovich, pp. 11-33. 
SYKES, G. M. (1958), The Society of Captives: A Study of a Maximum Security Prison, Princeton, Princeton University Press.

THOMAS, W. I. e D. S. Thomas (1928), The Child in America: Behavior Problems and Programs, New York, Knopf.

THOMPSON, J. (2005), “The New Visibility”, Theory, Culture \& Society, 22 (6), pp. 31-51.

TONRY, M. (2004), Thinking about Crime: Sense and Sensibility in American Penal Culture, New York, Oxford University Press.

UGGEN, C., S. Wakefield e B. Western (2005), "Work and Family Perspectives on Reentry”, in J. Travis e C. Visher (eds.), Prisoner Reentry and Public Safety in America, Cambridge, Cambridge University Press, pp. 209-243.

VAN KEMPEN, E. T. (1994), “The Dual City and the Poor: Social Polarisation, Social Segregation and Life Chances', Urban Studies, 31 (7), pp. 995-1015.

VARESE, F. e M. Yeish (2000), “The Importance of Being Asked: The Rescue of Jews in Nazi Europe”, Rationality and Society, 12 (3), pp. 307-334.

VETLESEN, A. J. (2005), Evil and Human Agency: Understanding Collective Evildoing, Cambridge, Cambridge University Press.

VETLESEN, A. J. (1994), Perception, Empathy, and Judgment: An Inquiry into the Preconditions of Moral Performance, University Park, Penn State Press.

WACQUANT, L. (2005), "Symbolic Power in the Rule of the «State Nobility»", in L. Wacquant (ed.), Pierre Bourdieu and Democratic Politics: The Mystery of Ministry, Cambridge, Polity Press, pp. 133-150.

WACQUANT, L. (2001), “Deadly Symbiosis: When Ghetto and Prison Meet and Mesh”, Punishment \& Society 3 (1), pp. 95-134.

WACQUANT, L. (1999), “Urban Marginality in the Coming Millennium”, Urban Studies, 36 (10), pp. 1639-1647.

WACQUANT, L. (1997), “For an Analytic of Racial Domination”, Political Power and Social Theory, 11, pp. 221-234.

WACQUANT, L. (1996), “The Rise of Advanced Marginality: Notes on its Nature and Implications”, Acta Sociologica, 39 (2), pp. 121-139.

YOUNG, J. (1999), The Exclusive Society: Social Exclusion, Crime and Difference in Late Modernity, London, Sage.

ŽIŽEK, S. (2006), How to Read Lacan, London, Granta Books.

ŽIŽEK, S. (1992/2008), Enjoy your Symptom!, New York, Routledge.

\section{NOTAS}

1. Os meus agradecimentos ao meu ex-colega e amigo Guilherme Marques Pedro pela tradução deste artigo.

2. Sobre as prisões secretas ver Stafford Smith (2007); sobre o "excepcionalismo" americano, ver Tonry (2004).

3. Outras objecções que a prisão transporta consigo incluem: o provável fluxo de familiares dos detidos, que podem criar problemas ao sistema de assistencia social presente na comunidade local, integrar actividades criminosas, contribuir para o abuso e tráfico de drogas, e causar uma 
série de outros problemas à comunidade; o medo que os detidos não originários da comunidade anfitriã, possam, uma vez libertados, optar por nela se estabelecerem, assim comprometendo a segurança pública; o baixo nível de 'orgulho cívico', e o receio de o valor da propriedade e do investimento venha a diminuir como resultado da localização da prisão; o receio de uma dependência económica e política dos assuntos internos cada vez maior face ao exterior; e, no caso particular das regiões locais, os potenciais danos ambientais (Farrington, 1992; Krause, 1992; Murray, 2007; Shichor, 1992). Relativamente a este aspecto, estudos recentes apresentam dúvidas face à possibilidade de as prisões irem de encontro aos objectivos económicos nas áreas rurais mais empobrecidas. Por exemplo, na sua análise da prisão rural no estado de Nova Iorque, desde 1977 a 2000, King et al. (2003) não encontraram nenhum impacto significativo das prisões nas taxas de desemprego e nos salários per capita das comunidades anfitriãs.

4. Baseio-me aqui no estudo fascinante levado a cabo por Richard Kearney (2003) sobre como os medos e as ansiedades que residem nas profundezas do Self encontram refúgio no misterioso triumvirato mitológico de estranhos, deuses e monstros. Ironicamente, no preciso dia em que escrevia estas linhas (4 de Junho de 2006) um helicóptero foi desviado e aterrou no quintal da prisão de Korydallos em Atenas, resgatando dois detidos e levantando voo em seguida numa cena holywoodesca que deixou as autoridades estupefactas. Quatro dias depois, e durante a frenética cobertura mediática do incidente, os inquietados residentes locais organizaram uma manifestação de protesto, reclamando a deslocalização das infra-estruturas prisionais para longe da cidade. No mesmo tom, $\mathrm{O}$ presidente da câmara municipal prestou a seguinte declaração à imprensa: "De novo fica provado que a presença de prisões na cidade dificilmente torna mais seguro quer o sistema correctivo, quer as centenas de cidadãos inocentes e crianças que vivem e circulam diariamente a poucos metros de distância dos estabelecimentos em causa. Este escape cinemático traz, uma vez mais à superfície a questão da relocalização das prisões. A paciência desta cidade esgotou-se. Apelamos às autoridades, ao Ministro da Justiça e a todos os partidos políticos que assumam as suas responsabilidades" (Ta Nea, 5 de Junho de 2006). É bom recordar que, apesar das garantias oficiais no sentido contrário, o complexo prisional de Korydallos ainda não foi relocalizado, devido sobretudo às preocupações financeiras que têm que ver com a construção de prisões novas fora de Atenas.

5. Para aqueles que não estão familiarizados com os vários tipos de estabelecimentos prisionais em Inglaterra e no País de Gales, devemos notar que, na sua maioria, as prisões locais servem para manter os detidos à espera de julgamento num tribunal próximo. Também podem deter condenados cuja pena é de curta duração, assim como condenados com penas mais pesadas e que acabaram de ser julgados estando ainda por determinar a sua classificação de segurança e consequente alojamento noutra prisão. Não é infrequente que detidos de longa data retornem às condições locais, ou para cumprir as respectivas sentenças, ou para serem realojados, ou quando a transferência temporária da "prisão-mãe" seja considerada necessária "por motivos de ordem e disciplina."

6. Ver também para efeito do mesmo autor, aprovado pelo conselho editorial e pendente de publicação, Cheliotis, L. K. (2008a) "Before the Next Storm: Some Evidence-based Reminders about Temporary Release", International Journal of Offender Therapy and Comparative Criminology.

7. Ver também para efeito do mesmo autor, aprovado pelo conselho editorial e pendente de publicação, Cheliotis, L. K. (2008b) Governing through the Looking-Glass: Perception, Morality and Neoliberal Penality, Ph.D. dissertation, Institute of Criminology, University of Cambridge.

8. Ver também para efeito do mesmo autor, aprovado pelo conselho editorial e pendente de publicação, Cheliotis, L. K. (2008a) 'Before the Next Storm: Some Evidence-based Reminders about Temporary Release', International Journal of Offender Therapy and Comparative Criminology.

9. Para os mais atentos à origem linguística, não são coincidências que a palavra 'território' e a sua raiz latina territorium são supostos derivativos de terrere, que significa 'assustar', 'aterrorizar', 'afugentar'. 
10. Ver também para efeito do mesmo autor, aprovado pelo conselho editorial e pendente de publicação, Cheliotis, L. K. (2008b).

11. Para efeito comparar ainda a Brighenti, A. (2007) 'Visibility: A Category for the Social Sciences', Current Sociology 55 (3): 323-342.

12. Contornarmos a concepção l'art pour l'art de academismo é evadirmo-nos da falsa reivindicação de neutralidade moral, mas não necessariamente cair na armadilha da "lógica do tribunal científico" - um assunto bicudo que não posso analisar por motivos de espaço).

\section{RESUMOS}

Michel Foucault tinha razão em observar que há monstros à espreita cujas formas mudam com o passar da história do conhecimento e, ainda assim, nem a história do conhecimento, nem as histórias das assimetrias de poder que daí advêm são alguma vez escritas pela mão invisível de Júpiter ou suspensas pela intervenção messiânica de Dei ex machina. Se o nosso objectivo é o de descrever holisticamente, e talvez também o de ajudar a combater, a cada vez mais crescente exclusão do outro, então precisamos de recuar e trazer para diante da nossa lupa os processos sociais e humanos pelos quais, em primeiro lugar, percepções generalizadas e avaliações morais ganham conteúdo, forma e orientações reaccionárias. Desta forma, este artigo toma como ponto de partida a tese de Bauman segundo a qual a suspensão de processos de comunicação e as práticas de exclusão geográfica servem para abafar as précondições cognitivas e emocionais de qualquer juízo moral, assim estabelecendo os fundamentos da sua própria reprodução, como das suas consequências catastróficas. Se, como pretendo contra-argumentar, o envolvimento em formas físicas de comportamento exclusivista requer um peso moral significativo, este requer por sua vez a existência e a persistência de processos de comunicação. Em particular, a relegação cognitiva dos outros para o estatuto de seres moralmente inferiores é que espoleta, e perpetua, as emoções necessárias para o envolvimento moralizante em formas físicas de comportamento exclusivista.

Michel Foucault was no doubt right to observe that 'there are monsters on the prowl, whose form changes with the history of knowledge', yet neither history of knowledge, nor the histories of power asymmetries this reflects and fuels in turn, are ever written by 'the invisible hand of Jupiter' or upended thanks to the messianic intervention of Dei ex machina. If we are holistically to account for, and perhaps also help overturn, the ever-growing physical exclusion of Otherness, then we need to take a step backwards and bring under our magnifying glass the social, manmade processes by which mass perceptions and mass moral evaluations are given content, shape, and reactionary directions in the first place. In so doing, this article takes issue with the Baumanian thesis that, in banning or suspending communication, practices of geographical exclusion serve to stifle the cognitive as well as emotional preconditions of any moral judgement, thereby also laying the foundations for their own reproduction, and for the reproduction of their catastrophic consequences. If, as it is counterargued, engagement in physical forms of exclusionary behaviour requires significant moral weight, moral weight itself requires the existence, and indeed persistence, of communication. In particular, cognitive relegation of others to the status of morally lesser beings is what sets in motion, and perpetuates, the emotions necessary for moralising engagement in physical forms of exclusionary behaviour. 
ÍNDICE

Keywords: exclusion, otherness, space/place, cognition, emotions

Palavras-chave: exclusão, alteridade, espaço/lugar, cognição, emoções

\section{AUTOR}

\section{LEONIDAS K. CHELIOTIS}

Lecturer (eq. Assistant Professor) em Criminologia e Director, Centro de Justiça Criminal, Queen Mary, Universidade de Londres

cheliotis@qmul.ac.uk 